\title{
CHARACTERISTICS OF IMMOBILIZED LACTOBACILLUS DELBRUECKII IN A LIQUID-SOLID FLUIDIZED BED BIOREACTOR FOR LACTIC ACID PRODUCTION
}

\author{
HENIAN WANG, MINORU SEKI \\ AND SHINTARO FURUSAKI \\ Faculty of Engineering, The University of Tokyo, Tokyo 113
}

Key Word: Biochemical Engineering, Immobilized Lactobacillus delbrueckii, Lactic Acid Fermentation, Calcium Alginate, Cell Release, Nutrient Effect, Fluidized Bed Bioreactor

\begin{abstract}
Continuous lactic acid production using immobilized $L$. delbrueckii was investigated. To evaluate the performance of the liquid-solid fluidized bed reactor using immobilized cells, the release rate of free cells from support surfaces and contribution of the free cells, which co-exist with immobilized cells in the broth, to lactic acid production were studied quantitatively. The results showed that the free cells played an important role at low dilution rate. If the dilution rate was increased, the effect of free cells on lactic acid production decreased quickly. Increasing the holdup of immobilized particles in the reactor lowered the contribution of free cells to the lactic acid production. Finally, the performance of the reactor was studied under the conditions of low growth nutrients. The results suggested that there was more active cell growth within the gel beads in the fluidized bed reactor than in the cell recycle reactor using membrane.
\end{abstract}

\section{Introduction}

Lactic acid is widely used in the food, cosmetic and pharmaceutical industries. Lactic acid can also be used to prepare polylactic acid, which is a prospective biodegradable polymer. Lactic acid production through fermentation presently provides about $50 \%$ of the world supply, but productivity is very low in conventional batch processes. However, the productivity can be increased by employing cell immobilization methods that provides high cell density in the bioreactor.

Immobilized cells entrapped within polymeric matrices have been extensively studied for lactic acid production $1,2,5,10,11,12,14)$. Calcium-alginate is a popular matrix for immobilization of lactic acid-producing bacteria because it has no toxicity to microorganisms and can provide a simple method of immobilization.

There are several reports on lactic acid fermentation using immobilized cells in stirred-tanks ${ }^{15)}$, packed beds ${ }^{1}$, $7,11,12)$ and fluidized bed reactors ${ }^{5}$. Generally speaking, for a product-inhibition reaction, the choice of plug flow reactors will be advantageous. However in lactic acid fermentation, both lactic acid and lactate ion inhibit growth and lactic acid production of the microorganisms. Of these, undissociated lactic acid shows more severe inhibition. Therefore we cannot expect good results in a packed bed reactor because $\mathrm{pH}$ cannot be precisely controlled along the column. The lowering of $\mathrm{pH}$ will enhance the inhibition of the undissociated lactic acid. On the other hand, stirred tanks are not suitable for lactic acid fermentation using immobilized cells as the shear stress exerts serious

\footnotetext{
* Received October 3, 1994. Correspondence concerning this article
} should be addressed to $S$. Furusaki. effects on supports such as Ca-alginate whose surfaces are occupied by the growing cells.

Little work has been carried out concerning evaluation of the performance of the reactor for lactic acid production using immobilized cells under continuous operation conditions. Furthermore, the cell leakage behavior from the support surface and the contribution of free cells in the broth to the lactic acid production have rarely been studied ${ }^{13)}$. Fluidized bed reactors possess a number of advantages over other bioreactors, which include intimate phase mixing, prevention of clogging and a wide range of operation conditions. Thus in this study, a fluidized bed bioreactor was employed for lactic acid production using immobilized cells. First, the cell release rate was discussed. Then, the contribution of free cells to lactic acid production in the reactor was quantitatively investigated. The behavior of immobilized cells and the performance of the reactor were estimated. Finally, the effects of growth nutrients on the reactor performance were investigated.

\section{Experimental}

\subsection{Microorganism and medium}

L. delbrueckii IFO 3534, obtained from the Institute of Fermentation, Osaka, Japan, was used in this study. The mediums for refresh culture and seed culture are the same as those described by Hongo et al. ${ }^{3)}$. The medium of fermentation culture is as follows: $50 \mathrm{~kg} / \mathrm{m}^{3}$ glucose, 20 $\mathrm{kg} / \mathrm{m}^{3}$ yeast extract, $8.0 \mathrm{~kg} / \mathrm{m}^{3}$ polypeptone, $2.0 \mathrm{~kg} / \mathrm{m}^{3}$ $\mathrm{K}_{2} \mathrm{HPO}_{4}, 0.5 \mathrm{~kg} / \mathrm{m}^{3} \mathrm{MgSO}_{4} \cdot 7 \mathrm{H}_{2} \mathrm{O}, 0.1 \mathrm{~kg} / \mathrm{m}^{3} \mathrm{NaCl}$, and 2.5 $\mathrm{kg} / \mathrm{m}^{3} \mathrm{CaCl}_{2} \cdot 2 \mathrm{H}_{2} \mathrm{O}$. The medium used for the preparation 


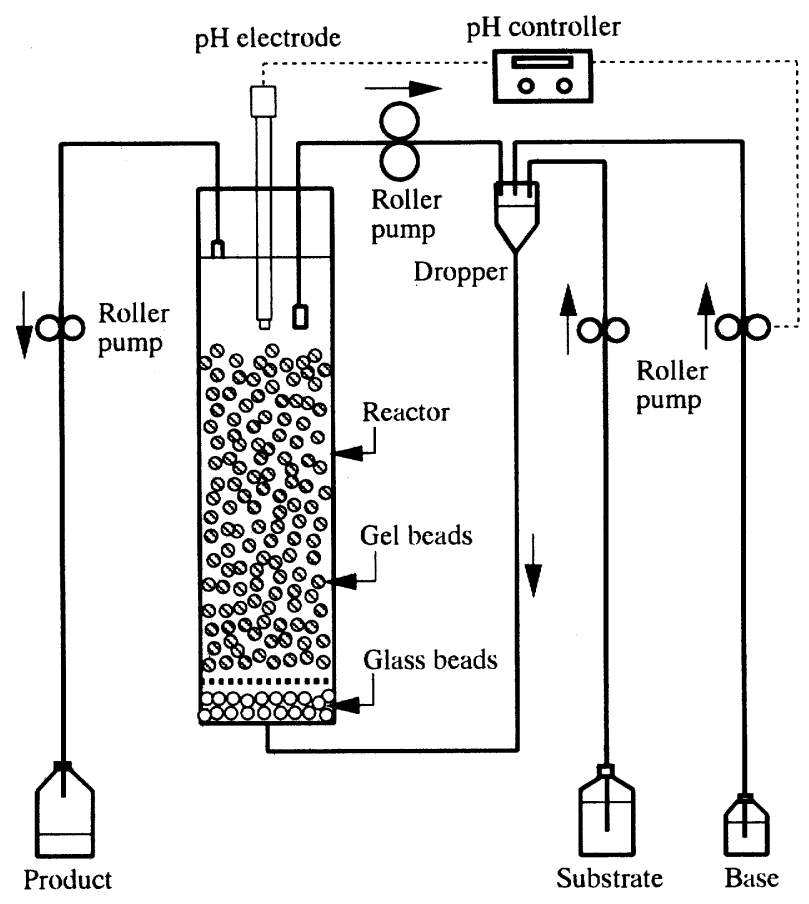

Fig. 1 Schematic diagram of the liquid-solid fluidized bed reactor

of the immobilized cells (washing medium) consists of 10 $\mathrm{kg} / \mathrm{m}^{3}$ glucose, $10 \mathrm{~kg} / \mathrm{m}^{3}$ yeast extract, $4.0 \mathrm{~kg} / \mathrm{m}^{3}$ polypeptone, $0.5 \mathrm{~kg} / \mathrm{m}^{3} \mathrm{MgSO}_{4} \cdot 7 \mathrm{H}_{2} \mathrm{O}$ and $0.1 \mathrm{~kg} / \mathrm{m}^{3} \mathrm{NaCl}$ at $\mathrm{pH}$ $=5.5-6.0$. Glucose and $\mathrm{CaCl}_{2} \cdot 2 \mathrm{H}_{2} \mathrm{O}$ were autoclaved separately.

After $24 \mathrm{~h}$ of refresh culture, $10 \mathrm{ml}$ of the inoculum was inoculated to $100 \mathrm{ml}$ of the seed culture medium. The cells cultivated for $15 \mathrm{~h}$ in the seed culture medium were harvested by centrifugation and washed once by the washing medium. Cultivations were carried out at $315 \mathrm{~K}$.

\subsection{Cell immobilization}

The harvested cells were suspended in the washing medium and mixed with $4 \%(\mathrm{w} / \mathrm{v})$ sodium alginate solution of the same volume. The mixture obtained was dripped through a needle into $1.5 \% \mathrm{CaCl}_{2} \cdot 2 \mathrm{H}_{2} \mathrm{O}$ solution (the wash medium contained $1.5 \% \mathrm{CaCl}_{2} \cdot 2 \mathrm{H}_{2} \mathrm{O}$ ), then the gel beads were hardened in the same solution for about 30 minutes before washing.

\subsection{Experimental setup}

Figure 1 is a schematic diagram of the experimental setup used in this study for the continuous operation. The reactor is made of transparent polycarbonate, $38 \mathrm{~mm}$ in inner diameter and has $200 \mathrm{ml}$ of effective volume. The broth circulation was maintained by a peristaltic pump (Furue Science, Tokyo, Japan).

\subsection{Kinetic experiments}

The growth rate of free cells was measured during the initial logarithmic phase of growth. The cells harvested from the seed culture were inoculated into the medium containing $0-100 \mathrm{~g} / 1$ glucose $(\mathrm{pH}=5.5), 0-45 \mathrm{~g} / 1$ lactate $(\mathrm{pH}$ $=6.2), 0.5-2.8 \mathrm{~g} / \mathrm{l}$ lactic acid $(\mathrm{pH}=4.3)$, respectively and $20.0 \mathrm{~g} / \mathrm{l}$ yeast extract, $8.0 \mathrm{~g} / \mathrm{l}$ polypeptone, $2.0 \mathrm{~g} / 1 \mathrm{KH}_{2} \mathrm{PO}_{4}$, $0.5 \mathrm{~g} / \mathrm{l} \mathrm{MgSO} \mathrm{gS}_{4} \cdot 7 \mathrm{H}_{2} \mathrm{O}, 0.1 \mathrm{~g} / \mathrm{l} \mathrm{NaCl}$, and $2.5 \mathrm{~g} / \mathrm{C} \mathrm{CaCl}{ }_{2} \cdot \mathrm{H}_{2} \mathrm{O}$.

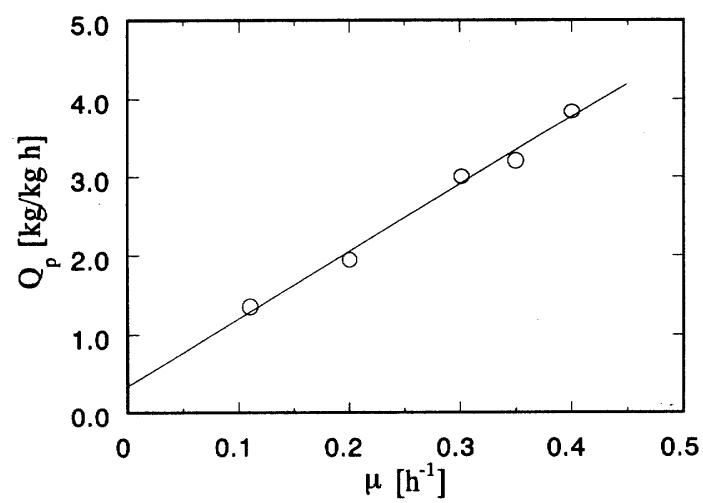

Fig. 2 Relationship between specific production rate $\left(Q_{p}\right)$ and specific growth rate $(\mu)$

The cell growth was measured in a $500 \mathrm{ml}$ flask agitated with a magnetic stirrer, and the $\mathrm{pH}$ in the broth was controlled by automatic addition of $3 \mathrm{~N} \mathrm{NaOH}$. The specific production rate was obtained from continuous free cell fermentations.

\subsection{Continuous operation}

The immobilized gel beads were incubated in the liquid-solid fluidized bed reactor. The fluid level control in the continuous culture was carried out with a peristaltic pump. Steady state conditions in continuous operation were reached after supplying seven to nine reactor-volumes of the culture medium. Fermentations for immobilized cells were carried out at $315 \mathrm{~K}$ and the $\mathrm{pH}$ of the broth solution was kept at 5.5 by automatic addition of base (3M $\mathrm{NaOH})$.

\subsection{Analysis}

Lactic acid concentration was determined by HPLC. Analysis was performed with TSKgel SCK $\left(\mathrm{H}^{+}\right.$type) (Tosoh, Japan) using $0.5 \% \mathrm{H}_{3} \mathrm{PO}_{4}$ as the carrier solution. Detection was carried out with a UV detector (Shimadzu, Japan) at $210 \mathrm{~nm}$. The cell concentration in the broth was determined by measurement of the optical density at 660 $\mathrm{nm}$.

\section{Results and Discussion}

\subsection{Fermentation kinetics of $L$. delbrueckii}

The specific growth rate $^{16)} \mu$, incorporating the Monod dependence on the substrate and growth inhibition by lactate $\left(\mathrm{L}^{-}\right)$and the undissociated lactic acid $(\mathrm{LH})$, was shown as:

$$
\mu=\frac{\mu_{m} S}{K_{s}+S}\left(1-\frac{L^{-}}{L_{m}^{-}}\right) \exp \left(-\frac{L H}{L H_{m}}\right)
$$

The constants of $\mu_{\mathrm{m}}, K_{s}, L_{m}^{-}$, and $L H_{m}$ were estimated as $0.458 h^{-1}, 1.69 \times 10^{-3} \mathrm{~mol} / 1,0.82 \mathrm{~mol} / 1$ and $0.012 \mathrm{~mol} / 1$ from kinetic studies. Here, it is assumed that $90 \%$ of glucose can be converted to $\left(L^{-}+L H\right)^{7}$. Therefore, $\mathrm{S}$ calculated from $\left(L^{-}+L H\right)$ was used in calculating the $\mu . K_{a}=$ $1.41 \times 10^{-4} \mathrm{~mol} / \mathrm{l}$, the dissociation constant of lactic acid, was also used to calculate the compositions of $L^{-}$and $L H$.

The specific production rate $Q_{p}$ was found to 


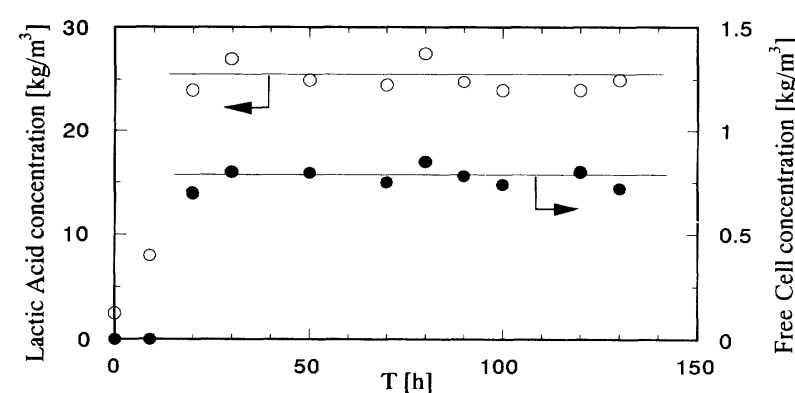

Fig. 3 Time course of continuous immobilized cell fermentation $\left(\mathrm{D}=0.22 \mathrm{~h}^{-1}, \mathrm{R}=1.85 \mathrm{~mm}, \varepsilon_{\mathrm{s}}=0.17\right)$

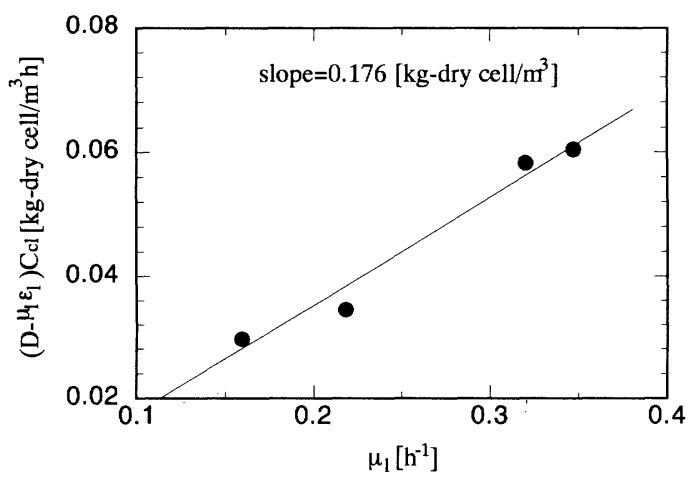

Fig. 4 Relationship between (D- $\left.\mu_{1} \varepsilon_{1}\right) \mathrm{C}_{\mathrm{cl}}$ and $\mu_{1}$ (see Eq.(8))

increase proportionally with the specific growth rate $\mu$ (Luedeking and Piret model ${ }^{6)}$ ).

$$
Q_{p}=a \mu+b
$$

The constants $\mathrm{a}$ and $\mathrm{b}$ of the Luedeking and Piret model were evaluated to be $8.77 \mathrm{~g} / \mathrm{g}$ and $0.33 \mathrm{~g} /(\mathrm{g} \cdot \mathrm{h})$ from the results of continuous free cell fermentation (Fig. 2).

\subsection{Continuous operation}

Figure 3 shows an example of continuous immobilized cell fermentation. The steady state was reached after about 40 hours. The steady state lasted until the experiment was finished after $140 \mathrm{~h}$ of operation without any operational troubles such as $\mathrm{pH}$ distribution along the column, dead zones and plugging problems observed in packed-bed reactors 1,11$)$. Additional experiment showed that the steady state could be maintained for more than two weeks. This verified that a fluidized bed reactor is suitable for lactic acid fermentation using immobilized cells.

\subsection{Cell release rate}

Cell growth occurring in the gel beads, preferentially near the bead surfaces, results in a certain rate of cell release into the fermentation medium. The cells released into the medium will grow at a growth rate depending on the fermentation conditions. Therefore, considerations on cell release rate and contribution of the free cells to lactic acid production are necessary to evaluate the performance of a reactor using immobilized cells for lactic acid production.

At the steady state, the effluence of cells from the reactor is balanced by the release of cells from the gel bead surfaces and the growth of free cells. Under our experi-

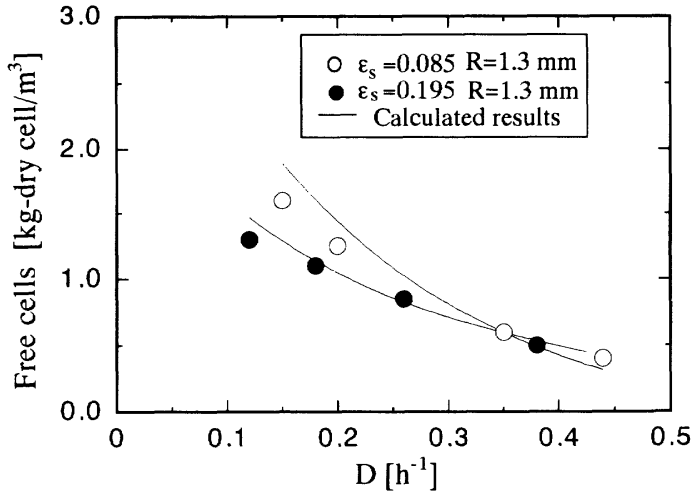

Fig. 5 Effects of dilution rate on free cell concentration for different solid holdups in immobilized cell fermentation

mental conditions, the reactor system can be considered as a continuous stirred tank reactor. Then, the mass balance of free cells at steady state can be written as follows ${ }^{13)}$ :

$$
D C_{c l}=\varepsilon_{l} C_{c l} \mu_{l}+V_{s}
$$

Here, $V_{s}$ is cell release rate from gel beads. Assuming cell density on the bead surfaces (maximum cell density) is $C_{s}$, and also considering the contribution of cell growth inside the gel beads to the cell release, we can write the following equations:

$$
\begin{aligned}
& V_{s}=\frac{4 \pi R^{2} l C_{s} \mu_{s}}{\frac{4}{3} \pi R^{3}} \varepsilon_{s} \\
& V_{s}=\frac{3 \varepsilon_{S}}{R} l C_{S} \mu_{S} \\
& \delta=\frac{3 \varepsilon_{s}}{R} l C_{s} \\
& D C_{c l}=\varepsilon_{l} C_{C l} \mu_{l}+\delta \mu_{S} \\
& \mu_{S}=\mu_{l}
\end{aligned}
$$

Here, $\mu_{s}$ and $\mu_{l}$ are the specific growth rate on the surface of gel beads and in the medium, respectively.

$l$ is the effective depth from the surface where cells grow at the rate governed by $C_{s}$. The effective depth $l$ may be affected by the properties of the gels and the behavior of immobilized cells, such as gel strength and interactions between cells. It can be considered that the cell release rate from the gel beads is equivalent to the growth rate of a cell layer with a cell density of $\mathrm{C}_{\mathrm{s}}$ and a specific growth rate of $\mu_{s}$

From Eq. (6), we can write Eq. (8) as follows,

$$
\left(D-\varepsilon_{l} \mu_{l}\right) C_{C l}=\delta \mu_{l}
$$

From experimental data, the depth $l$ was calculated and found to be $5.18 \times 10^{-6} \mathrm{~m}$ using $\mathrm{R}=1.47 \times 10^{-3} \mathrm{~m}$ and $\varepsilon_{s}$ $=0.086$ (Fig. 4). Here, $C_{s}=200 \mathrm{~kg}$-dry cell $/ \mathrm{m}^{3}$ is used (Korgel, et $\left.a l^{4}{ }^{4}\right)$. Then concentration of free cells in the broth under various operating conditions can be calculated using Eq. (9). 


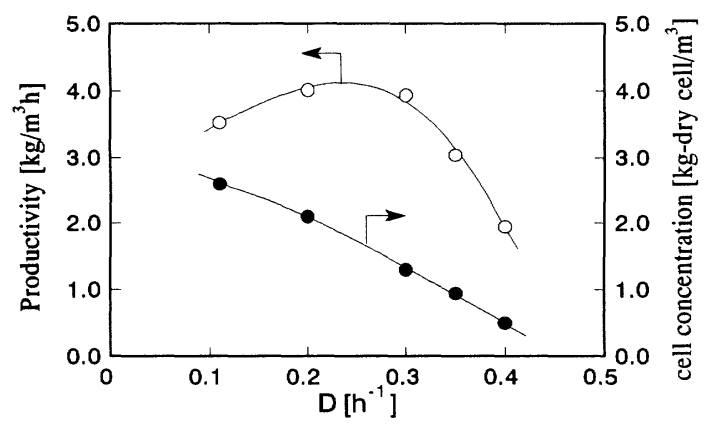

Fig. 6 Effects of dilution rate on lactic acid productivity and cell concentration in free cell fermentation (Experimental results)

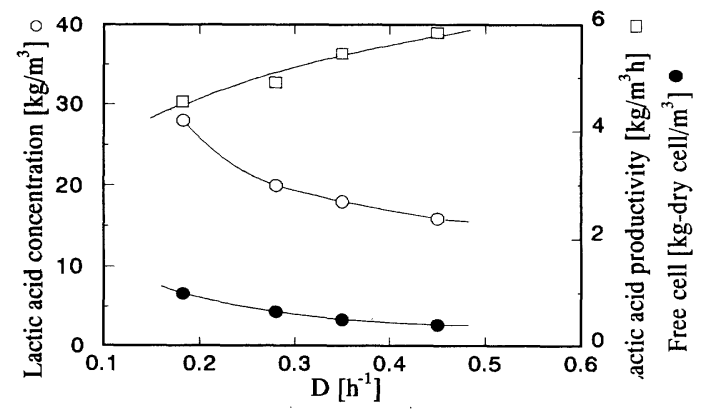

Fig. 7 Effects of dilution rate on lactic acid production and free cell concentration in immobilized cell fermentation $\left(\varepsilon_{\mathrm{s}}=0.175, \mathrm{R}=1.5 \mathrm{~mm}\right)$

$$
C_{c l}=\frac{3 l \varepsilon_{S} C_{S} \mu_{l}}{R\left(D-\varepsilon_{l} \mu_{l}\right)}
$$

To estimate the contribution of free cells to lactic acid production, we calculate the growth rate of free cells using Eq. (1) from measured (or given) values of $\left(L^{-}+L H\right)$ in the broth, and then calculate the production rate of free cells using $C_{c l}$ from Eq. (9) and Eq. (2). On the other hand, if free cell concentrations in the broth are measured, the lactic acid concentration can be calculated using Eq. (1) and Eq. (9). Therefore, the free cell concentration may be used as a measure of lactic acid concentration in the fermentation system with immobilized cells.

Figure 5 shows the relationship between concentration of free cells in the broth and dilution rate (D). The calculated results from measured values of $\left(L^{-}+L H\right)$ using Eq. (9) agree well with the experimental data. Free cell concentration decreased with increasing dilution rate. In contrast to free cell fermentation (Fig. 6), immobilized cell fermentation (Fig. 7) shows lower free cell concentration in the broth. This means that with increasing solid holdup in the reactor, the residence time of free cells in the reactor becomes shorter and also the growth rate of free cells becomes lower due to higher product concentration in the broth. Thus, free cell concentration decreases despite the fact that increased solid holdup could give more surface area for cell release.

\subsection{Production rate of lactic acid}

For comparison, the experimental result of lactic acid production using free cells is shown in Fig. 6. The

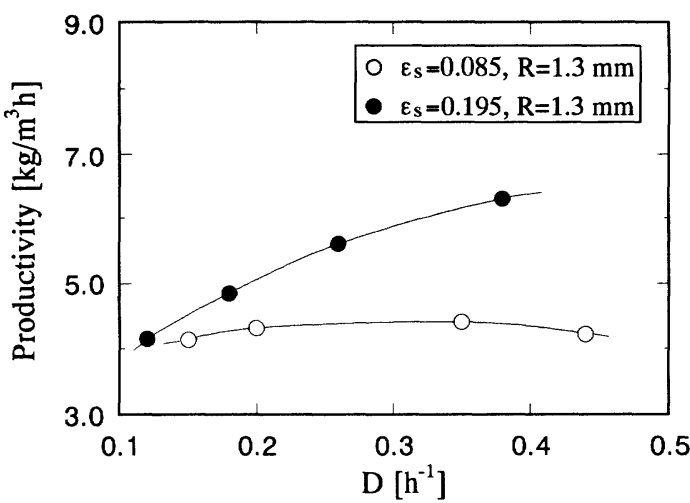

Fig. 8 Effects of dilution rate on lactic acid productivity for different solid holdups

production rate of lactic acid decreased when the dilution rate became higher. This resulted from the washout effect which was caused by high dilution rate.

Figure 7 shows the effects of dilution rate on the production rate of lactic acid using immobilized cells at the conditions of $\varepsilon_{s}=0.175$ and $\mathrm{R}=1.5 \mathrm{~mm}$. The productivity increased significantly with increasing dilution rate because a higher dilution rate resulted in a lower product inhibition. As immobilized cells are maintained in the reactor, " wash out " can be avoided even at a higher dilution rate. Therefore, immobilized cell fermentation can be operated under a higher dilution rate for obtaining higher productivity. At $\mathrm{D}=0.45 \mathrm{~h}^{-1}$, a productivity of $5.85 \mathrm{~g} / \mathrm{l} \cdot \mathrm{h}$ was reached. At the same time, the free cells decreased to a relatively low level $(0.4 \mathrm{~g} / \mathrm{l})$.

Figure 8 shows the effects of dilution rate on productivity at different solid holdups in the reactor. The productivity increased with increasing gel-bead holdup. Although productivity is not linear with gel-bead holdup, it is obvious that the use of higher bead holdup is advantageous in improving the productivity even at a high dilution rate. On the other hand, at lower solid holdup condition, it can be seen that productivity did not increase with increasing dilution rate. This result implies that with increasing dilution rate, the decrease of lactic acid production rate by free cells was compensated by the increase of lactic acid production rate by immobilized cells. So there was little decrease in total productivity with increasing dilution rate. Under conditions of higher solid holdup, the productivity increased with increasing dilution rate because the contribution of free cells became small.

\subsection{Contribution of free cells}

Figure 9 and Fig. 10 show the contributions of free cells and the immobilized cells to lactic acid production. The contributions were calculated using total lactic acid concentrations in the broth from the experiments. The calculating method is the same as described in section 2.3. The results showed that when gel bead holdup in the reactor was low (Fig. 9), the free cells played an important role in productivity at a low dilution rate. With increasing dilution rate, the contribution of free cells decreased and the contribution of immobilized cells became larger. On the 


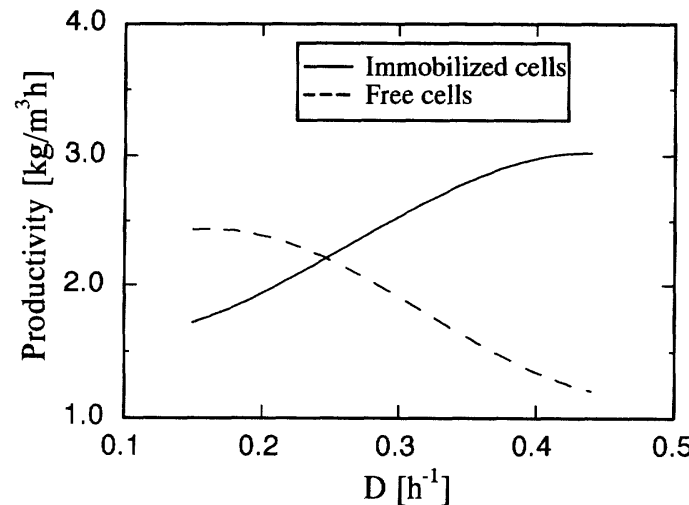

Fig. 9 Contributions of free and immobilized cells to lactic acid production under conditions of lower solid holdup $\left(\varepsilon_{\mathrm{s}}=0.085, \mathrm{R}=1.3 \mathrm{~mm}\right)$

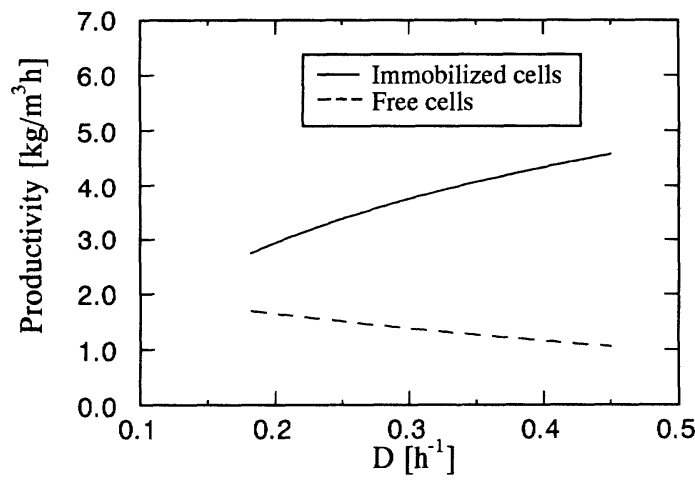

Fig. 10 Contributions of free and immobilized cells to lactic acid production under conditions of higher solid holdup $\left(\varepsilon_{\mathrm{s}}=0.175, \mathrm{R}=1.5 \mathrm{~mm}\right)$

other hand, under higher gel bead holdup conditions (Fig. 10), the contribution of immobilized cells to total productivity was important not only at a high dilution rate, but also at a lower dilution rate because the gel-entrapped cells had a large population in the reactor, and because free cell concentrations became low. In practical operation, it is expected that much larger solid holdup and a moderate dilution rate may be used for obtaining higher productivity. The contribution of free cells to lactic acid production will become unimportant because the large solid holdup brings about high lactic acid concentration in the broth and this decreases lactic acid production rate by the free cells.

\subsection{Effects of growth nutrients}

Relatively high concentrations of yeast extract and polypeptone (growth nutrients) are essential for batch lactic acid fermentation and for the startup period of continuous fermentation because cells require these nutrients for growth. However, for continuous steady state fermentations using immobilized cells, such a high concentration of nutrients is not necessary. Therefore, a minimal level of growth nutrients should be kept in the feed to lower substrate costs.

Effects of yeast extract and polypeptone concentrations in the feed on reactor performance were investigated. The concentrations of yeast extract ranged from $20.0 \mathrm{~g} / \mathrm{l}$ to $2.5 \mathrm{~g} / \mathrm{l}$ and polypeptone from $8.0 \mathrm{~g} / \mathrm{l}$ to $1.0 \mathrm{~g} / \mathrm{l}$. The ratio

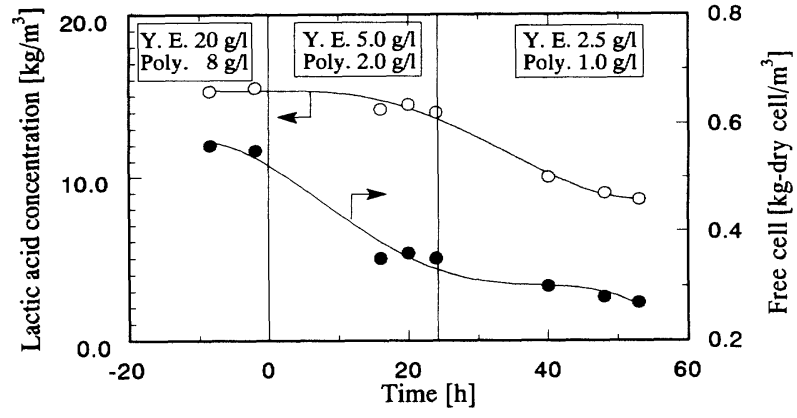

Fig. 11 Effects of nutrients on lactic acid production and free cell concentration $\left(\mathrm{R}=1.5 \mathrm{~mm}, \mathrm{D}=0.44 \mathrm{~h}^{-1}, \varepsilon_{\mathrm{s}}=\right.$ 0.18 )

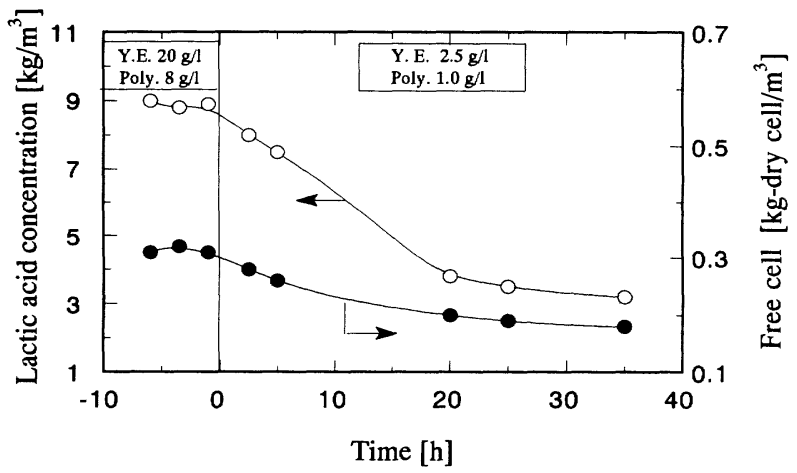

Fig. 12 Effects of nutrients on lactic acid production and free cell concentration $\left(\mathrm{R}=1.47 \mathrm{~mm}, \mathrm{D}=0.49 \mathrm{~h}^{-1}, \varepsilon_{\mathrm{s}}=\right.$ 0.086)

of yeast extract to polypeptone was kept at 2.5. The experimental results are shown in Fig. 11 and Fig. 12. It can be concluded that reactor productivity was not affected significantly when concentrations of yeast extract and polypeptone in the feed were reduced to $5.0 \mathrm{~g} / \mathrm{l}$ and $2.0 \mathrm{~g} /$, respectively. However, reactor productivity decreased dramatically when concentrations of yeast extract and polypeptone were as low as $2.5 \mathrm{~g} / \mathrm{l}$ and $1.0 \mathrm{~g} / \mathrm{l}$, respectively. Free cell concentration in the broth also dropped to a lower level. From these observations, it is clear that a certain concentration of nutrients is required for cell growth, cell maintenance and lactic acid production.

Ohleyer et al. ${ }^{8,9)}$ reported the effects of yeast extract concentration on the performance of a cell recycle reactor using $L$. delbrueckii. They showed that a steady state could be obtained, even when reducing yeast extract concentration to $2.5 \mathrm{~g} / \mathrm{l}$ from $25.0 \mathrm{~g} / \mathrm{l}$ and to $2.0 \mathrm{~g} / \mathrm{l}$ from $12.6 \mathrm{~g} / \mathrm{l}$. A very small amount of nitrogen appeared to be required to maintain the steady state in the cell recycle reactor. Although the strain used here is different from their studies, our results show that higher nutrient concentration is necessary for immobilized cell fermentation to maintain a steady state. This higher nutrient requirement indicates that more active growth occurs in the immobilization support than in the cell recycle reactor (Ohleyer et al ${ }^{8,99}$ ). 


\section{Conclusions}

A liquid-solid fluidized bed reactor with immobilized cells was used to perform continuous lactic acid fermentation without any operational problems. The performance of the reactor was investigated under different conditions.

Cell release rate and contribution of free cells to lactic acid production were studied quantitatively. The results showed that under low gel holdup and low dilution rate conditions, free cells played a significant role in lactic acid production. However, increasing solid holdup decreased the free cell concentration in the broth due to high lactic acid concentration and also decreased the contribution of the free cells to lactic acid production.

The effects of growth nutrients on reactor performance were investigated. The immobilized cell reactor can be operated at lower nutrient feed $(5.0 \mathrm{~g} / \mathrm{l}$ yeast extract and $2.0 \mathrm{~g} / 1$ polypeptone) without sacrificing reactor performance. The results suggested that there is more active cell growth in the gel beads in the L-S fluidized bed reactor than in the cell recycle reactor using membrane.

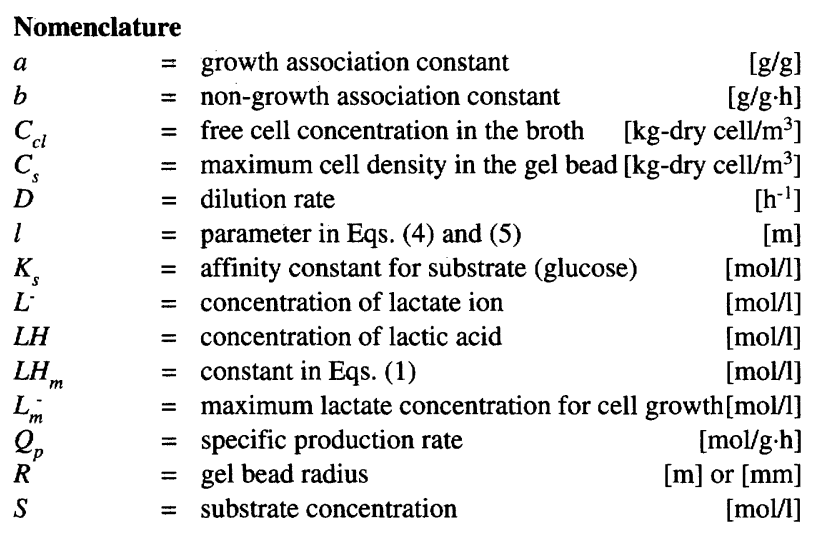

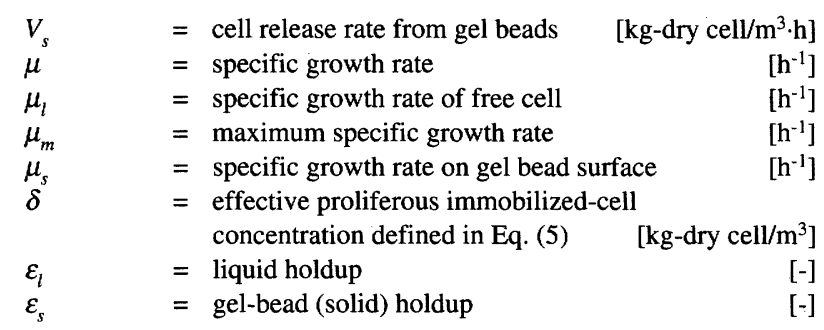

\section{Literature Cited}

1) Boyaval, P. and J. Goulet: Enzyme Microbiol. Technol., 10, 725-728 (1988)

2) Dong, G.Q., R. Kaul, and Bo. Mattiasson: Appl. Microbiol. Biotechnol., 36, 309- 314 (1991)

3) Hongo, M., Y. Nomura, and M. Iwahara: Appl. Environ. Microbiol., 52, 314-319 (1986)

4) Korgel, B. A., A. Rotem, and H. G. Monbouquette: Biotechnol. Prog., 8, 111-117, (1992)

5) Krischke, W., M. Schröder, and W. Trösch: Appl. Microbiol. Biotechnol., 34, 573- 578 (1991)

6) Luedeking, R. and E. L. Piret: J. Biochem. Microbiol. Technol. Eng., 1, 431-459 (1959)

7) Nomura, Y., M. Iwahara, and M. Hongo: Biotechnol. Bioeng., 30 , 788-793 (1987)

8) Ohleyer, E., H. W. Blanch, and C. R. Wilke: Appl. Biochem. Biotechnol., 11, 317-332 (1985)

9) Ohleyer, E., H. W. Blanch, and C. R. Wilke: Appl. Biochem. Biotechnol., 11, 457- 463 (1985)

10) Roukas, T. and P. Kotzekidou: Enzyme Microbiol. Technol., 13, 3338 (1991)

11) Roy, D., J. Goulet, and A. Le. Duy: J. Dairy Sci., 70, 506-513 (1987)

12) Stenroos, S. S.,Y. Y. Linko, and P. Linko: Biotechnol. Lett., 4, 159164 (1982)

13) Sun, Y. and S. Furusaki: J. Ferment. Bioeng., 69, 102-110 (1990)

14) Tuli, A., R. P. Sethi, P. K. Khana, S. S. Mareaha, and J. F. Kennedy: Enzyme Microbiol. Technol., 7, 164-168 (1985)

15) Yabannavar, V. M. and D. I. C. Wang: Biotechnol. Bioeng., 37, 1095 $1100(1990)$

16) Yabannavar, V. M. and D. I. C. Wang: Biotechnol. Bioeng., 37, $544-$ 550 (1990) 